\title{
Alkoholistforsorg og kriminalforsorg
}

\author{
Af overlæge C. J. HANSEN, Risskov
}

Flere gode grunde taler for netop nu at diskutere samarbejde mellem kriminalforsorg og alkoholistforsorg. Inden disse grunde nævnes, findes det rimeligt at understrege, at Danmark vel næppe kan siges at have en klart struktureret alkoholistforsorg, som man finder den i de $\varnothing$ vrige nordiske lande. I Danmark har man i mange år ladet det frie initiativ bestemme, hvor og hvorledes man skulle sætte ind, og således er det i realiteten stadig, selv om man i 1960 i sygehusloven foretog ændringer, som pegede i retning af en fastere struktur. I sygehuslovens $\S 16$ findes, om ikke så skarpt formuleret, bestemmelser om, at alkoholister har krav på behandling i ambulatorier, der kan drives af stat, kommuner eller private - i sidste fald, hvis sygehusvæsenet ikke kan eller vil oprette ambulatorier. Man ventede i 1960, at ændringen af sygehusloven ville medf $\varnothing$ re en opblomstring af alkoholistbehandlingen - ikke mindst fordi det i hvert fald indirekte af loven fremgik, at alkoholisme måtte være at betragte som sygdom — og som en sygdom af en sådan alvor, at staten måtte refundere $100 \%$ af udgifterne ved dens behandling i lighed med, hvad der er tilfældet med behandling af epidemiske sygdomme og k $\varnothing$ nssygdomme. Der synes dog ikke at have været noget stærkt incitament i loven, for der skete ikke så meget i de første år derefter, og i de sidste år er der trods umiskendelige fremskridt heller ikke udfoldet en så stor aktivitet som фnskeligt.

Det, som man kan kalde ambivalenskonflikten, er en mulig årsag hertil. Arentsen ${ }^{1}$ ) skrev i 1961: „I de sidste år er der sket en gradvis og endnu ikke fuldbyrdet ændring i lægernes og den almindelige befolknings syn på alkoholisten. Det drejer sig om en ændring af vore attituder, og denne har nu fundet udtryk i lovgivningen. I denne lovgivning er - som i næsten enhver lov - at spore såvel en arv fra fortiden som en foruddiskontering af fremtiden. Fra det forgangne kender vi holdningen over for alkoholisten som den synde- og lastefulde, den samfundsforstyrrende og skadevoldende, som den det gæelder om at beskytte familien, b $\phi \mathbf{r -}$ nene og hele samfundet imod. Det nye syn på alkoholisten er en betragtning af ham som et sygt menneske, en lidende, som vi læger skal hjælpe, en person, som vi skal beskytte mod ham selv.

I anden form forelagt på Dansk Kriminologisk Selskabs møde den 5. december $1973 \mathrm{i}$ forbindelse med dr. Kettil Bruuns foredrag om alkoholisme (jfr. ovenfor p. 226-234).

1) Kaj Arentsen: Hvad skal vi stille op med vore alkoholister? Månedsskrift for praktisk lægegerning 1961: 483—498. 
Lovgivningen giver udtryk for denne ambivalens, denne dobbelthed $\mathrm{i}$ indstillingen, men med hovedvægten lagt på det moderne syn. Fremtiden skal vise, om der i lovens administration opnås klog balance mellem disse modstridende attituder". Man kan næppe sige, at ambivalenskonflikten er mindre aktuel end i 1961, for i befolkningens og i massemediers syn på alkoholisten finder man stadig begge synspunkter, og i mange behandlingssituationer er ambivalenskonflikten særlig stærk, netop fordi der i disse år er en tendens til blandt behandlere at betragte alkoholister ikke som syge, men som mennesker, hvis adfærd er uhensigtsmæssig, og det $g \phi r$ det naturligvis ikke lettere for centraladministration og andre myndigheder at følge eventuelle $\phi$ nsker om oprettelse af behandlingssteder, når man oven i købet er inde i en $\phi$ konomisk nedgangsperiode.

I indledningen omtaltes, at der er en række grunde til netop nu at diskutere samarbejde mellem alkoholistforsorg og kriminalforsorg. Blandt disse grunde kan nævnes:

1) Ændringen af borgerlig straffelov den 1.7.1973 med bortfald af specielle sanktioner og dermed med $\phi$ nsket om at g $\phi$ re noget andet for alkoholister — d.v.s. at skabe et andet alternativ til almindelig straf end de specielle anbringelsesformer, som var mulige $\mathrm{f} \phi \mathrm{r}$ 1. 7. 1973.

2) Andringen af domspraksis og løsladelsespraksis i de senere år - allerede flere år f $\phi \mathbf{r}$ straffelovsændringen således at der anvendes flere betingede domme og foretages flere prøvel $\varnothing$ sladelser med specialvilkår om alkoholistbehandling end tidligere.

3) Muligheden for, at alkoholismen i samfundet er i tiltagen. Man regner i almindelighed med i det danske samfund, at ca. 100.000 mennesker er alkohollidende, men ingen ved reelt hvor mange. Man ved blot, at der er sket en forbrugsstigning $i$ et tempo på ca. $1 / 2$ liter koncentreret alkohol pr. år. pr. person over 15 år, således at der $\mathrm{nu}$ er tale om et salg af alkohol svarende til mere end $10 \mathrm{l}$ koncentreret alkohol pr. person over 15 år imod ca. $3 \frac{1}{2}$ 4 liter i 1950'erne. Der tales meget om unges voksende alkoholmisbrug eller måske alkoholoverforbrug.

Der er næppe grund til at omtale den muligt $\phi$ gede alkoholisme i samfundet nærmere, idet man må erkende, at man ganske mangler unders $\phi$ gelser over hyppigheden af alkoholisme, hvilket har nær sammenhæng med de definitoriske vanskeligheder, men også sammenhæng med, at interessen for alkoholforskning i Danmark er ringe, hvilket næsten må kaldes en speciel dansk tradition. 
Det vil være rimeligt kort at skildre de aktuelle behandlingsinstitutioner. Der er i $\varnothing$ jeblikket 37 alkoholambulatorier i drift godkendt efter sygehuslovens $\S 16$. Det er utvivlsomt for lidt, og de er meget ujævnt fordelt over landet med en overvægt i StorK $\varnothing$ benhavn, medens store provinsbyer er ganske uden behandlingsmuligheder. En stor del af disse ambulatorier drives enten af private foreninger eller af kommuner og er placeret uden for sygehusvæsenet. Det har nok været mest skuffende, at det psykiatriske hospitalsvæsen, såvel det amtskommunale som det statslige, ikke har fulgt lovens henstilling om at påtage sig alkoholistbehandling. Også andre steder end i disse ambulatorier drives i ret stor udstrækning ambulant alkoholistbehandling, deriblandt af Kriminalforsorgen, og da især på Centralkontoret i København, medens Kriminalforsorgens provinsafdelinger enten henviser til almindelige alkoholistambulatorier eller med eller uden bistand af konsulenter selv foranstalter behandling. Samarbejdende med ambulatorier findes 5 behandlingshjem og 2 plejehjem, men disse institutioner tager sig næppe i større omfang af klienter med behandlingsvilkår i relation til betinget dom eller pr $\phi v e l \phi s l a d e l s e$. Hvor mange alkoholister der $\mathrm{i}$ alt er $\mathrm{i}$ behandling $\mathrm{i}$ landets ambulatorier, ved ingen med sikkerhed, og begrebet, at være $\mathrm{i}$ behandling“ er også flydende, men størrelsesordenen må være $10.000-$ 12.000 , og $3.000-4.000$ nye patienter modtages årligt.

Under straffelovrådets forhandlinger inden ændringen af borgerlig straffelov 1.7.1973 blev Retslægerådet stillet over for en række spфrgsmål om særforanstaltninger, og i straffelovrådets „Betænkning om de strafferetlige særforanstaltninger" findes Retslægerådets svar på en række spørgsmål. ${ }^{2}$ ) Til spørgsmål om foranstaltninger over for alkoholister svares bl. a.: „Der er grund til at beklage, at sygehuslovens mulighed for at skabe et landsdækkende behandlingsapparat for alkoholister ikke er udnyttet. I så fald kunne man - ved henvisning til sådanne ambulatorier - pege på et alternativ til frihedsstraf for alkoholmisbrugende kriminelle. Det er i $\varnothing$ jeblikket praksis, at Dansk Forsorgsselskab til eksisterende ambulatorier henviser betinget $d \phi$ mte og et stort antal pr $\phi$ vel $\phi$ sladte med specialvilkår om alkoholistbehandling. Imidlertid kan det erfaringsmæssigt være vanskeligt at få ambulatorierne til at påtage sig behandlingen af de pågældende - enten fordi der ikke findes ambulatorium på klientens bopæl, eller fordi eksisterende ambulatorier i nogle tilfælde afviser at behandle forsorgsselskabets klienter under henvisning til, at arbejdet er for byrdefuldt $\mathrm{i}$ forhold til personalenormeringen. Det må efter sygehuslovens forudsætninger anses for tvivlsomt, om det er be-

2) Betænkning om de strafferetlige særforanstaltninger (Betænkning $\mathrm{nr} .667,1972)$ p. $172 \mathrm{ff}$. 
rettiget at afvise sådanne klienter, der i lighed med alle andre alkoholister eller formodet alkoholskadede har adgang til offentligt drevne ambulatorier. Som situationen er i фjeblikket, må det imidlertid konstateres, at der - inden en væsentlig udbygning af alkoholistforsorgen har fundet sted - næppe kan opstilles et realistisk alternativ til frihedsstraf for den omhandlede persongruppe“.

I erkendelse af, at mulighederne for at få behandlet kriminelle alkoholister er begrænsede både af geografiske og af andre grunde, kunne det overvejes, om Kriminalforsorgen burde åbne sine egne ambulatorier eller skabe andre behandlingsfaciliteter i forbindelse med Kriminalforsorgens afdelinger. Det er dog næppe rationelt at oprette et sådant eget system. Dels vil det blive meget kostbart, og dels er der ideologiske betænkeligheder knyttet dertil. Erfaringer viser, at der ikke er grund til at tro, at kriminelle med specielle alkoholistbehandlingsvilkår ikke skulle kunne behandles i almindelige ambulatorier. Forudsætningen er blot, at ambulatorierne vil påtage sig opgaven, derunder også en tilsynsopgave, som er uløseligt knyttet til behandlingsopgaven, fordi den samlede procedure - behandling og tilsyn - netop iklke bør splittes op i sine elementer. Man må betænke, at alkoholistbehandling, således som den ydes i Danmark, f $\varnothing$ rst og fremmest er en social-pædagogisk eller social-psykiatrisk behandling, som netop b $\phi \mathrm{r}$ hvile på en realistisk opfattelse af, hvad målet er, og behandlingens og tilsynets mål må være det samme, nemlig så vidt muligt at undgå kriminelt recidiv, og dette kunne tænkes opnået ved at forhindre fortsat alkoholmisbrug, selv om sammenhængen naturligvis ikke altid er så enkel, at ophør af alkoholmisbrug også medfører oph $\phi r$ af kriminel aktivitet. Efter min opfatelse bør man ikke drøfte, hvor man skal behandle kriminelle alkoholister, men om man skal behandle dem, idet jeg hermed dels tænker på, at der i de senere års kriminologiske litteratur ganske klart er givet udtryk for en almen modvilje over for behandling, i hvert fald over for tvungen behandling, dels tænker på, at det er vanskeligt at påvise nogen nedsat kriminel recidivrisiko selv efter velgennemf $\phi r t$ alkoholistbehandling. Man kan fristes til at sige, at man ved anvendelse af behandlingsvilkår er betænkelig nær ved at ville behandle specifikt for én afvigelse, hvor hensigten reelt er at sфge at undgå udtryk for anden afvigende adfærd, i dette tilfælde kriminalitet. Mere drastisk kan det udtrykkes således, at man næppe uden videre $b \phi r$ godtage, at man iværksætter terapeutiske foranstaltninger over for en formodet sygdom som led i en retlig sanktion, med mindre det er indlysende, at det er sygdommen, som har medført lovbruddet. Et sådant standpunkt er imidlertid i h $\varnothing$ j grad diskutabelt. Personligt mener jeg ikke, at det er forekrt at behandle alkoholister 
og at gøre det i konsekvens af specialvilkår, det være sig betingede eller ubetingede specialvilkår. ${ }^{3}$ ) Men forudsætningen må være, at vilkårene bruges med stor omtanke og konsekvens.

Man kunne spфrge, om resultater af behandling af kriminelle alkoholister lader sig sammenligne med resultater af behandling af andre alkoholister, og hertil kan svares, at man i Klinikken for Alkohollidende i Århus igennem flere år har foretaget tentative opg $\varnothing$ relser af resultater, hvilket har vist, at der ikke er nogen forskel i den alkoholmæssige prognose til trods for, at der blandt alkoholister med specialvilkår er flere ugunstige prognostiske faktorer end i den gruppe, som udg $\phi$ res af de $\varnothing$ vrige patienter.

Forudsætningen for, at der kommer noget ud af behandlingsfors $\phi \mathrm{g}$, må være, at patienten eller klienten er motiveret for behandling, og at han er forberedt på, at behandling vil blive iværksat, og at den vil blive $\mathrm{f} \phi \mathrm{rt}$ igennem med konsekvens, så lang tid klienten har behov derfor, eller dog så lang tid som hans motivering kan holde dertil. Der skønnes at være visse mangler i behandlingssystemet i $\varnothing$ jeblikket, idet ganske mange alkoholister findes dårligt forberedt på, hvad der vil møde dem efter en betinget dom eller efter prøveløsladelse, hvilket kan skyldes brist i oplysning om, hvorledes alkoholistbehandling s $\varnothing$ ges udf $\varnothing \mathrm{rt}$, men også kan skyldes, at specialvilkår anvendes i noget større omfang end egentlig påkrævet.

Planlægningsudvalget vedrørende den frie kriminalforsorg har i februar-marts 1973 foranstaltet en unders $\phi$ gelse af, hvorledes status er for de 1800 klienter, som har specialvilkår i forbindelse med betinget dom eller prøvel $\varnothing$ sladelse. Det viser sig, at $6 \%$ af disse klienter blot har vilkår om at afholde sig fra misbrug af alkohol, medens $16 \%$ har ubetingede alkoholistbehandlingsvilkår og $78 \%$ betingede alkoholistbehandlingsvilkår. Disse 1800 klienter udg $\varnothing \mathrm{r}$ i alt $29 \%$ af samtlige klienter, som er under tilsyn af Kriminalforsorgen. Det er videre oplyst, at $27 \%$ af disse 1800 klienter med specialvilkår var i behandling på unders $\varnothing$ gelsestidspunktet, deraf $1 / 3$ i ambulatorium og $2 / 3$ var i behandling på anden vis - ganske overvejende hos tilsynsførende. Det er forståeligt, at fordelingen var meget forskellig inden for de enkelte grupper efter vilkårets formulering, således at der var flest, nemlig $48 \%$, i behandling blandt de klienter, som havde ubetingede alkoholistbehandlingsvilkår. Et af unders $\emptyset$ gelsens resultater er,

3) Her og i det følgende benyttes den terminologi, at et betinget specialvilkår er et vilkår, som efter sin formulering henskyder til tilsynsmyndighedens afgørelse, om behandling skal iværksættes eller ej, mens et ubetinget specialvilkår går ud på, at behandling skal iværksættes i forbindelse med betinget dom eller prøveløsladelse. Se herved Kriminalforsorgsudvalgets betænkning om vilkår ved betingede domme og prøveløsladelser (Bet. nr. 519, 1969) p. $35 \mathrm{f}$. 
at $52 \%$ af klienterne ikke fandtes at have noget behandlingsbehov, hvilket umiddelbart må overraske. Det kan føre til den slutning, at alkoholistbehandlingsvilkår anvendes for hyppigt, men muligvis er denne slutning forkert, idet der iblandt sådanne klienter ganske givet er mange, hvis alkoholisme ikke til enhver tid er behandlingskrævende, og der tænkes hermed især på unge klienter, hvis alkoholoverforbrug snarest er miljøbetinget, og som intet behandlingsbehov har, hvis de kommer i et gunstigere miljø end det milj $\phi$, de befandt sig i ved domfældelse. Man har så blot ment det korrekt at anvende specialvilkår for at sikre behandling, såfremt en sådan blev forn $\varnothing$ den. De erfaringer, som man har i Klinikken for Alkohollidende i Århus, viser, at langt størstedelen af de fra Kriminalforsorgen henviste klienter har et klart objektivt behandlingsbehov, idet de er addiktive alkoholister, og en stor del af disse har da også et subjektivt behandlingsbehov, som tillader en behandling at forløbe lige så godt som hos de patienter, der ikke er i behandling i konsekvens af specialvilkår. Det er en klar bestræbelse hos hele klinikkens personale, at der ikke gøres forskel på de to patientgrupper, hvilket er muligt, fordi socialrådgiverne $\mathrm{i}$ klinikken er beskikket som de omtalte vilkårspatienters tilsynsf $\varnothing$ rende og indtager i relation til klienten ganske samme rolle, som når de er andre patienters ansvarlige socialrådgivere, idet hovedansvaret for behandlingen ligger hos socialrådgiverne og ikke hos lægerne, som optræder som konsulenter med den opgave at behandle klart definerede lægelige problemer, selv om man naturligvis må tilf $\varnothing j e$, at grænser imellem socialrådgiveres og lægers arbejde er flydende, ligesom i $\phi$ vrigt grænserne også mellem sekretærers og socialrådgiveres og lægers arbejde i en sådan klinik er flydende. Man lægger i en behandlingstilrettelæggelse af vilkårspatienter megen vægt på, at behandlingen er realistisk, og at vilkår skal og må opfattes efter sit pålydende. Det vil sige, at man ikke helt deler den ikke sjældent udtalte opfattelse, at et vilkår er et behandlingstilbud. Snarere er man tilbøjelig til at formulere sig således, at et behandlingsvilkår er en foranstaltning, som træder i stedet for straf, men som skal følges, hvis indberetning med deraf f $\not$ lgende ubehageligheder skal undgås. Meget h $\phi$ jtideligt udtrykt er klinikkens opfattelse den, at der $\mathrm{b} \phi \mathrm{r}$ være alvor og hæderlighed bag de fastsatte vilkår, således at deres betydning ikke mindskes, således at de ikke ,devalueres".

Som anf $\varnothing \mathrm{rt}$ tidligere er de umiddelbare behandlingsresultater lige så gode hos de kriminelle som hos de ikke-kriminelle, når det drejer sig om selve alkoholismen, men det kan ikke skjules, at man ikke føler sig overbevist om, at den kriminelle recidivrisiko påvirkes helt afg $\varnothing$ rende. Det er særdeles vanskeligt i en så inhomogen gruppe at danne sig et sk $\varnothing$ n over, hvorledes den 
kriminelle recidivrisiko er, men det er klart, at der optræder kriminelt recidiv i alle grupper, også de grupper, hvor behandlingsresultaterne er gode. Når kriminelt recidiv optræder, kan man ikke tale om noget godt socialt resultat, selv om der jo på andre sociale områder er opnået ganske gode resultater, således at stabilt arbejde, fastholden af bopæl, evt. genoptagelse af ægteskab eller etablering af ægteskab er opnået. I forbindelse hermed $\mathbf{b} \phi \mathbf{r}$ omtales et meget væsentligt problem, som har betydning for al alkoholistbehandling af ambulant art. Patienternes boligproblem er ofte et hovedproblem, og ikke mindst for de betinget d $\varnothing$ mte og for de prøvel $\varnothing$ sladte er boligproblemet i den situation, som de er i umiddelbart efter dom eller prøvel $\varnothing$ sladelse, præget af utilfredshed med boligforhold, idet patienterne ofte bor i dårligt værelse, som er fremskaffet med mege kort varsel. Man savner i meget $h \varnothing j$ grad en speciel pensionatstype, præget dels af tolerance og venlighed, dels af en vis konsekvens. Man forestiller sig, at sådanne pensionater skulle rumme 8-10 personer med en maximal opholdstid på 3-6 måneder, og at opholdet dér skulle have tilbudskarakter og tjene til at skaffe god tid til fremskaffelse af en for patienten tilfredsstillende bolig — det være sig værelse eller lejlighed. At pensionatet skal være tolerant betyder også, at det skal kunne tåle alkoholrecidiver uden bortvisning, men blot med en intensivering af behandlingen som følge. Det er sandsynligt, at især pr $\varnothing$ vel $\varnothing$ sladte vil kunne drage nytte af sådanne pensionater, som b $\phi \mathbf{r}$ være små, men talrige, snarere end store og udstyret med et stort personale. Det er ikke meningen, at der skal udføres egentligt behandlingsarbejde i sådanne pensionater - behandlingsarbejdet må stadig påhvile den frie kriminalforsorg og de dermed samarbejdende alkoholklinikker.

I $\varnothing$ jeblikket kan man næppe sige, at der findes noget helt klart alternativ til straf $\mathrm{i}$ betydningen frihedsber $\varnothing$ velse, når talen er om alkoholister. Behandlingsapparatet er for spinkelt, geografisk ujævnt fordelt og måske heller ikke $i$ alle egne helt interesseret $i$ at påtage sig den særlige opgave, som det er at integrere behandlingen af kriminelle og ikke-kriminelle. Det må imidlertid klart være i samfundets interesse, at det tilkendegives, at kriminelle alkoholister har samme behandlingsret som andre alkoholister, og det f $\varnothing \mathrm{rer}$ os til den slutning, at Kriminalforsorgen b $\phi \mathrm{r}$ formulere sine $\varnothing$ nsker til alkoholistforsorgen, der inden for meget vide rammer er villig til at samarbejde trods manglende $\phi$ konomiske midler og trods manglende personale. Der er i alkoholistforsorgen aktuelt grobund for tanken om at finde et alternativ til frihedsstraf, og man kan i denne forbindelse fremhæve, at dette фnske om at skabe et alternativ til fritidsstraf netop for mange terapeuter har været baggrunden for, at de interesserer sig for begrebet alkoholisme, idet kriminalitet som social afvigelse i forbindelse med alkoholisme er særlig iøjnefaldende. 
Man kunne $\phi$ nske, at der var en mere udbredt viden om alkoholklinikkers arbejdsmetode og struktur. I forskellige sammenhænge og forskellige skrifter er der gjort rede for sådanne metoder, som kan være ret forskellige. Noget væsentligt er nok, at der er tale om tendens til en noget betænkelig generalisering $\mathrm{i}$ opfattelsen af behandling, idet Antabus meget ofte i diskussioner med betinget $d \varnothing m$ te og pr $\phi$ vel $\phi$ sladte kommer til at spille en for fremtrædende rolle. Man kan endog stadig se, at Antabus tillægges en ganske afgørende betydning for behandlingsforl $\varnothing$ bet, således at en eventuel forskel imellem indholdet $\mathrm{i}$ et såkaldt betinget vilkår og et ubetinget vilkår bliver reduceret til spørgsmålet, om Antabus skal anvendes eller ikke anvendes. Denne tendens til generálisering er meget skadelig for et samarbejde mellem alkoholistforsorg og kriminalforsorg. Disse bemærkninger sigter ikke til, at Antabus kan undværes $\mathrm{i}$ behandlingen, men det indtager $\mathrm{i}$ det daglige arbejde $\mathrm{i}$ en alkoholklinik slet ikke den rolle, som især den prøvel $\phi$ sladte tilsyneladende tror.

Forslag, som man kan stille i forbindelse med samarbejdet mellem alkoholistforsorg og kriminalforsorg, må herefter være, at kriminalforsorgen st $\varnothing$ tter alkoholistforsorgen i $\phi$ nsket om at få oprettet flere alkoholklinikker, at man får oprettet beskyttede pensionater af en type, som aktuelt ikke findes, at alle alkoholistbehandlingsinstitutioner modtager vilkårspatienter, og endelig at der s $\phi$ ges skabt en større forståelse for behandlingsproblematikken i kriminalforsorgens personalegrupper, f. eks. derved, at der foranstaltes en slags udvekslingstjeneste, således at forstå, at man også meget vel kunne tænke sig, at alkoholklinikkers personale kunne drage nytte af en tid at gøre tjeneste i den frie kriminalforsorgs afdelinger og også i fængselsvæsenets institutioner. I et vist omfang har noget sådant været fors $\phi$ gt tilsyneladende med betydelig personlig tilfredsstillelse for de implicerede. Et nært og rimeligt mål er, således som antydet tidligere, en meget realistisk vilkårsfastsættelse, således at behandlingsapparatet ikke overbelastes, og således at vilkårets betydning ikke overvurderes. Tvang som behandlingsmotiverende faktor er i relation til klienten næppe af positiv værdi, men et realistisk begrundet alkoholistbehandlingsvilkår er $\mathrm{i} h \not \mathrm{j}$ grad motiverende for terapeuter i denne sektor af samfundets behandlingsapparat for sociale afvigere.

C. J. Hansen 